\title{
Thermal Requirements of A Residential Apartment Building Through Natural Ventilation in the Warm and Humid Climate of Guwahati
}

\author{
Amal Barman \\ Department of Architecture \\ Jadavpur University \\ Kolkata, India
}

\author{
Dr. Madhumita Roy \\ Department of Architecture \\ Jadavpur University \\ Kolkata, India
}

\author{
Dr. Arpan Dasgupta \\ Department of Architecture \\ Amity University \\ Kolkata, India
}

\begin{abstract}
Natural resources that can provide better thermal comfort condition in warm and humid climate are natural ventilation and better shading performances. The effectiveness of natural ventilation and shading performance is determined by prevailing outdoor microclimate conditions and surrounding building envelops. This study investigates the thermal comfort performance in medium-rise residential apartment building through natural ventilation approach. This study was conducted at national games village, a G+6 storied residential apartment complex of Guwahati. Computer simulation is done using ENVI MET 4.0 microclimate software to calculate the parameters of air temperature, relative humidity, wind speed and surface temperature surfaces. After analysing the data's of each condition, the Predicted Mean Vote (PMV) has been obtained by using ENVI MET 4.0. The result shows that optimum WFR of $16.65 \%$ as proposed by GMDA bye-laws is not sufficient to lower air temperature as compared to the outside ambient temperature. However, in the case of applying natural ventilation strategies, comfort condition is achieved at night only.
\end{abstract}

Keywords - Natural ventilation, thermal comfort, Warm and humid climate, building form

\section{INTRODUCTION}

In recent time, the concept of sustainability has influenced the entire building industry in such a way that the futuristic approach of every single building has to be more climateresponsive. Due to the growing use of active ventilation system in the warm and humid climate of Guwahati, there is excessive use of energy in the building. Emission of a high percentage of greenhouse gases from these high energy building creates an uncomfortable outdoor thermal condition, especially in summer months. This growing problem is leading to a demand for the use of passive strategies for indoor climate modification. In a warm and humid climatic zone, Guwahati experiences a high daytime temperature of around $29^{\circ}$ to $34^{\circ}$ Celsius during summer and high relative humidity of $65 \%$ to $95 \%$. The building structures are also exposed to a high intensity of solar radiation and penetration. This uncomfortable situation has lead to the use of airconditioner as a compulsory alternative in almost every household of Guwahati to adjust the room temperature to the preferred level. This approach of using air conditioner becomes the main influential factor of high energy consumption in a building which contributes to a massive negative impact on the environment. As a green initiative to this problem, effective use of natural ventilation can be a suitable option for prevention of overheating and indoor climate modification since Guwahati has a $13.6 \%$ natural ventilation potential. Optimum use of natural ventilation can maximize its effects on thermal mass in reducing the indoor temperature in buildings up to a great extent. In the urban scale of neighbourhood planning, one of the design strategies that have the potential to overcome this climatic problem is the formation of a cluster of building around a central open space. A central open space is an enclosed area surrounded by adjoining building blocks and has opened to the sky in a housing complex. This planning concept can be well applied in the warm and humid climatic zone because it offers air exchange between hot and cool air during day and night. With proper orientation of building blocks, composition, and effective airflow pattern can be channelised to the central open space the first objective of this study is to investigate the performance of indoor air temperature compared to the ambient level. The purpose is to find significance on the difference in air temperature between ambient level and indoor due to the building design. The second objective is to investigate the performance of a natural ventilation approach to the indoor thermal condition. This objective will analyze the outdoor air temperature profile that influences the indoor room temperature and comfort level.

\section{BIO CLIMATIC FACTORS AND DEVELOPMENT CONTROL RULES OF GUWAHATI}

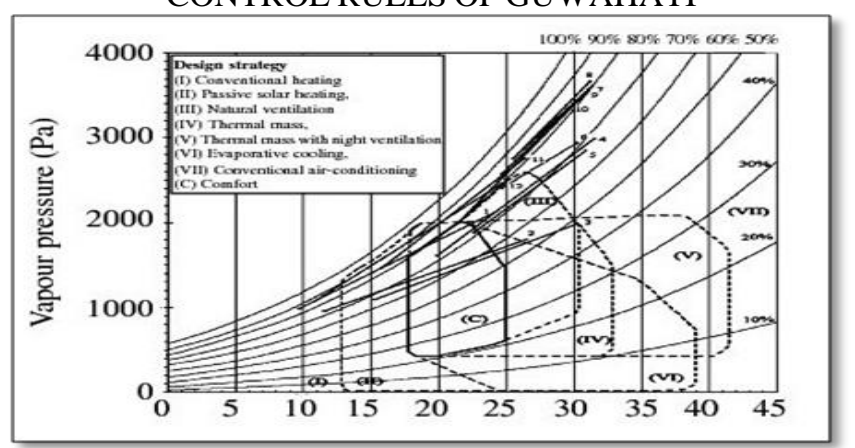

Fig. 2.1: Bio-climatic chart for Guwahati(Singh2007) 
Guwahati is located at a latitude of $26^{\circ} 1445^{\prime} \mathrm{N}$, the longitude of $91^{\circ} 7263^{\prime} \mathrm{E}$ and altitude of $54 \mathrm{~m}$ above sea level. This city has an annual average temperature of $24.21^{\circ} \mathrm{C}$ and relative humidity remains above $70 \%$ most of the time throughout the year. Prevailing wind direction is from SW to $\mathrm{NE}$ in summer with an average velocity of $6.9 \mathrm{~m} / \mathrm{s}$ and from $\mathrm{NE}$ to $\mathrm{SW}$ in winter with an average velocity of $5.47 \mathrm{~m} / \mathrm{s}$ (Table 2.3). The bio-climatic data of Guwahati project Comfort condition for about $14.17 \%$ time of the year in the winter and early summer months, whereas it shows that Conventional air-conditioning is required for $53.75 \%$ time of the year due to high humid climate during summer months. The usability of Natural Ventilation is about $16.7 \%$ time of the year. These figures represent the potential energy usage and potential energy savings depending upon the building design, orientation, and surrounding developments.

Regional Climate of Guwahati depends on Seasonal air temperatures, annual rainfall, Relative humidity and prevailing wind velocity and directions as per meteorological data of the city (Table.2.3).

Table.2.3: Meteorological data of Guwahati from Sept. 2018 to August 2019 (Source: Weatheronline.com)

\begin{tabular}{|c|c|c|c|c|c|c|}
\hline \multirow[t]{2}{*}{ Month } & \multirow[t]{2}{*}{$\begin{array}{l}\text { Rainfall } \\
(\mathrm{mm})\end{array}$} & \multicolumn{2}{|c|}{$\begin{array}{c}\text { Air } \\
\text { Temperature }\end{array}$} & \multirow{2}{*}{$\begin{array}{c}\text { Wind } \\
\text { Speed } \\
\text { Avg } \\
(\mathrm{Km} / \mathrm{h})\end{array}$} & \multirow[t]{2}{*}{$\begin{array}{c}\text { Wind } \\
\text { Direction }\end{array}$} & \multirow[t]{2}{*}{$\begin{array}{l}\mathrm{RH} \\
(\%)\end{array}$} \\
\hline & & Max. & Min. & & & \\
\hline Sept. 2018 & 179.72 & 31 & 24 & 4.2 & $\mathrm{~W}, \mathrm{SW}$ & $81 \%$ \\
\hline Oct. 2018 & 148.70 & 30 & 21 & 5.1 & E,SE,NE & $74 \%$ \\
\hline Nov. 2018 & 16.20 & 27 & 18 & 5.4 & E,SE,NE & $71 \%$ \\
\hline Dec. 2018 & 62.6 & 24 & 15 & 5.4 & E,SE,NE & $70 \%$ \\
\hline Jan. 2019 & 3.90 & 25 & 15 & 5.8 & E,SE,NE & $57 \%$ \\
\hline Feb. 2019 & 48.90 & 27 & 16 & 6.9 & E,SE,NW & $59 \%$ \\
\hline Mar. 2019 & 22.70 & 31 & 19 & 7.9 & E,SE,SW & $46 \%$ \\
\hline April 2019 & 224.20 & 34 & 23 & 7.4 & E,SE,SW & $57 \%$ \\
\hline May 2019 & 639.60 & 34 & 24 & 8.6 & E,SE,SW & $73 \%$ \\
\hline June 2019 & 536.80 & 35 & 26 & 5.2 & $\mathrm{~W}, \mathrm{SW}$ & $74 \%$ \\
\hline July 2019 & 1172.60 & 32 & 25 & 6.3 & W,SW & $85 \%$ \\
\hline August 2019 & 694.00 & 34 & 27 & 6.0 & $\mathrm{~W}, \mathrm{SW}$ & $78 \%$ \\
\hline
\end{tabular}

\section{A. Urban design regulations in Guwahati}

Urban design in Guwahati is governed by GMDA Building bye-laws and Guwahati Master Plan Zoning for the year 2025. The land-use zones contain residential areas, commercial areas, industrial areas, and Public/Semi-public areas. GMDA bye-laws specify the maximum number of floors, maximum building heights, road widths, building percentage (plot/ground coverage), floor area ratio (FAR), setbacks, etc.

\section{A.1 Residential apartment buildings in Guwahati}

The areas designated for residential use in Guwahati are divided into four distinguished plot typology of A, B, C, and $\mathrm{D}$ (Table 2.1.1). The minimum plot sizes for different residential sectors vary between below $670 \mathrm{~m}^{2}$ (sector A) to above $6670 \mathrm{~m}^{2}$ (sector D). The provisions regarding plot coverage, number of floors, building height, setbacks and the maximum FAR for each sector are shown in Table 2.1.1.
Table 2.1.1: GMDA bye-law provisions for residential use A, B, C and D

\begin{tabular}{|c|c|c|c|c|c|c|c|c|}
\hline \multirow{2}{*}{$\begin{array}{c}\text { Reside } \\
\text { ntial } \\
\text { plot } \\
\text { type }\end{array}$} & \multirow{2}{*}{$\begin{array}{l}\text { Road } \\
\text { Width } \\
\text { (m) }\end{array}$} & \multirow{2}{*}{$\begin{array}{c}\text { Max. } \\
\text { plot } \\
\text { covera } \\
\text { ge }\end{array}$} & \multirow{2}{*}{$\begin{array}{l}\text { Max. } \\
\text { no. of } \\
\text { floors }\end{array}$} & \multirow{2}{*}{$\begin{array}{c}\mathrm{Ma} \\
\mathrm{x} \\
\mathrm{FA} \\
\mathrm{R} \\
\end{array}$} & \multirow{2}{*}{$\begin{array}{l}\text { Max. } \\
\text { Heigh } \\
t(m)\end{array}$} & \multicolumn{3}{|c|}{ Setback (m) } \\
\hline & & & & & & $\begin{array}{c}\text { Fron } \\
t\end{array}$ & $\begin{array}{c}\mathrm{Bac} \\
\mathrm{k}\end{array}$ & $\begin{array}{c}\text { Side } \\
\mathrm{s}\end{array}$ \\
\hline \multirow{5}{*}{$\begin{array}{c}\text { A } \\
\text { (up to } \\
670 \\
\text { Sqm) }\end{array}$} & $\begin{array}{c}3.6 \text { to } \\
4.5 \\
\end{array}$ & $60 \%$ & $\mathrm{G}+2$ & $\begin{array}{c}1.0 \\
0 \\
\end{array}$ & 9.6 & 3.6 & 1.8 & 1.8 \\
\hline & $\begin{array}{c}4.5 \text { to } \\
6.6\end{array}$ & $60 \%$ & $\mathrm{G}+3$ & $\begin{array}{c}1.2 \\
5\end{array}$ & 12.6 & 4.5 & 2.4 & 2.4 \\
\hline & $\begin{array}{c}6.6 \text { to } \\
8.0\end{array}$ & $55 \%$ & $\mathrm{G}+4$ & $\begin{array}{c}1.5 \\
0 \\
\end{array}$ & 15.6 & 6.0 & 3.6 & 3.6 \\
\hline & $\begin{array}{c}8.0 \text { to } \\
15.0\end{array}$ & $50 \%$ & $\mathrm{G}+4$ & $\begin{array}{c}1.5 \\
0 \\
\end{array}$ & 15.6 & 6.0 & 3.6 & 3.6 \\
\hline & $\begin{array}{c}\text { Above } \\
15.0\end{array}$ & $50 \%$ & $\mathrm{G}+5$ & $\begin{array}{c}1.7 \\
5\end{array}$ & 18.6 & 9.0 & 4.2 & 4.2 \\
\hline \multirow{5}{*}{$\begin{array}{c}\text { B } \\
\text { (above } \\
670 \text { to } \\
1338 \\
\text { sqm) }\end{array}$} & $\begin{array}{c}3.6 \text { to } \\
4.5 \\
\end{array}$ & $50 \%$ & $\mathrm{G}+2$ & $\begin{array}{c}1.0 \\
0 \\
\end{array}$ & 9.6 & 3.6 & 1.8 & 1.8 \\
\hline & $\begin{array}{c}4.5 \text { to } \\
6.6 \\
\end{array}$ & $50 \%$ & $\mathrm{G}+4$ & $\begin{array}{c}1.2 \\
5 \\
\end{array}$ & 15.6 & 4.5 & 3.6 & 3.6 \\
\hline & $\begin{array}{c}6.6 \text { to } \\
8.0 \\
\end{array}$ & $50 \%$ & $\mathrm{G}+4$ & $\begin{array}{c}1.6 \\
0 \\
\end{array}$ & 18.6 & 9.0 & 4.2 & 4.2 \\
\hline & $\begin{array}{c}8.0 \text { to } \\
15.0\end{array}$ & $45 \%$ & $\mathrm{G}+8$ & $\begin{array}{c}1.7 \\
5 \\
\end{array}$ & 27.6 & 9.0 & 6.0 & 6.0 \\
\hline & $\begin{array}{c}\text { Above } \\
15.0\end{array}$ & $40 \%$ & $\mathrm{G}+8$ & $\begin{array}{c}1.7 \\
5\end{array}$ & 27.6 & $\begin{array}{c}=9.0 \\
<\end{array}$ & 6.0 & 6.0 \\
\hline \multirow{5}{*}{$\begin{array}{c}\mathrm{C} \\
\text { (above } \\
1338 \text { to } \\
6690 \\
\text { sqm) }\end{array}$} & $\begin{array}{c}3.6 \text { to } \\
4.5\end{array}$ & $50 \%$ & $\mathrm{G}+2$ & $\begin{array}{c}1.2 \\
5\end{array}$ & 9.6 & 3.6 & 1.8 & 1.8 \\
\hline & $\begin{array}{c}4.5 \text { to } \\
6.6 \\
\end{array}$ & $50 \%$ & $\mathrm{G}+5$ & $\begin{array}{c}1.2 \\
5 \\
\end{array}$ & 18.6 & 9.0 & 4.2 & 4.2 \\
\hline & $\begin{array}{c}6.6 \text { to } \\
8.0\end{array}$ & $45 \%$ & $\mathrm{G}+7$ & $\begin{array}{c}1.7 \\
5\end{array}$ & 24.6 & 9.0 & 5.5 & 5.5 \\
\hline & $\begin{array}{c}8.0 \text { to } \\
15.0\end{array}$ & $40 \%$ & $\begin{array}{c}\text { No } \\
\text { Limit }\end{array}$ & $\begin{array}{c}2.2 \\
5 \\
\end{array}$ & $\begin{array}{c}\text { No } \\
\text { Limit }\end{array}$ & 9.0 & $\begin{array}{c}=7.0 \\
<\end{array}$ & $\begin{array}{c}=7.0 \\
<\end{array}$ \\
\hline & $\begin{array}{c}\text { Above } \\
15.0\end{array}$ & $40 \%$ & $\begin{array}{c}\text { No } \\
\text { Limit }\end{array}$ & $\begin{array}{c}2.2 \\
5\end{array}$ & $\begin{array}{c}\text { No } \\
\text { Limit }\end{array}$ & $\begin{array}{c}=9.0 \\
<\end{array}$ & $\begin{array}{c}=7.0 \\
<\end{array}$ & $\begin{array}{c}=7.0 \\
<\end{array}$ \\
\hline \multirow{5}{*}{$\begin{array}{c}\mathrm{D} \\
\text { (above } \\
6690 \\
\text { sqm) }\end{array}$} & $\begin{array}{c}3.6 \text { to } \\
4.5 \\
\end{array}$ & $45 \%$ & $\mathrm{G}+3$ & $\begin{array}{c}1.2 \\
5 \\
\end{array}$ & 12.6 & 4.5 & 2.4 & 2.4 \\
\hline & $\begin{array}{c}4.5 \text { to } \\
6.6 \\
\end{array}$ & $45 \%$ & $\mathrm{G}+5$ & $\begin{array}{c}1.5 \\
0 \\
\end{array}$ & 18.6 & 9.0 & 4.2 & 4.2 \\
\hline & $\begin{array}{c}6.6 \text { to } \\
8.0\end{array}$ & $40 \%$ & $\mathrm{G}+7$ & $\begin{array}{c}1.7 \\
5\end{array}$ & 24.6 & 9.0 & 5.5 & 5.5 \\
\hline & $\begin{array}{c}8.0 \text { to } \\
15.0\end{array}$ & $40 \%$ & $\begin{array}{c}\text { No } \\
\text { Limit }\end{array}$ & $\begin{array}{c}2.2 \\
5\end{array}$ & $\begin{array}{c}\text { No } \\
\text { Limit }\end{array}$ & 9.0 & $\begin{array}{c}=7.0 \\
<\end{array}$ & $\begin{array}{c}=7.0 \\
<\end{array}$ \\
\hline & $\begin{array}{c}\text { Above } \\
15.0\end{array}$ & $40 \%$ & $\begin{array}{c}\text { No } \\
\text { Limit }\end{array}$ & $\begin{array}{c}2.5 \\
0\end{array}$ & $\begin{array}{c}\text { No } \\
\text { Limit }\end{array}$ & $\begin{array}{c}=9.0 \\
<\end{array}$ & $\begin{array}{c}=7.0 \\
<\end{array}$ & $\begin{array}{c}=7.0 \\
<\end{array}$ \\
\hline
\end{tabular}

The Residential apartment buildings in Guwahati are designated to develop in the plot typology of B, C, and D. The Residential apartment buildings are Naturally Ventilated since existing GMDA building bye-law strictly follows rules to provide minimum $16.67 \%$ WFR in every habitable room. All the habitable rooms should face at least one external wall or ventilation shaft wall with a minimum size of $3.0 \mathrm{~m} \times 3.0 \mathrm{~m}$. Natural ventilation is achieved by providing windows. Information on ventilation rate is needed when calculating the energy use of a building. In Guwahati, there is very little knowledge of the actual ventilation rate in apartments. Therefore, the ventilation rate is measured in a typical apartment.

\section{A.2 Natural ventilation in warm and humid climate of Guwahati}

The most common element of natural ventilation is openings in facades (windows). The keys to effective natural ventilation are the building orientation, the size and placing of the window openings. For buildings in warm-humid climates, it is recommended to create openings in different 
walls to allow cross ventilation for all rooms. This will enable the free flow of air throughout the building. Window sizes and location would determine the success of the ventilation strategy in a building. The openings on either side of the building enable cross-ventilation by creating different pressure zones. The size, location and orientation of these openings will affect the airflow inside the building. Therefore, the average interior air velocity depends on the size and location of the openings, the angle between the wind direction and the opening, and exterior wind velocity. Acceptable interior airflow depends on the temperature and humidity of the environment. At temperatures below $33^{\circ} \mathrm{C}$, an increase in air velocity increases the thermal comfort level.

During summer, in a typical warm and humid climate of Guwahati, thermal comfort can be achieved by the following aspects. Firstly, when the outside temperature is lower than the indoor temperature, ventilation can cool down the indoor air by replacing with the outside air. It also cools down the building structure. The second aspect is when the outside temperature is higher; ventilation can cause direct cooling on the human body by evaporation and convection.

\section{A.3 Physical parameters of thermal comfort in warm and humid climate}

According to ASHRAE, thermal comfort is defined as the "condition of mind that expresses satisfaction with the thermal environment" (ASHRAE, 1997). In warm and humid climate of Guwahati, the air temperature ranges from $24^{\circ}$ to $30^{\circ} \mathrm{C}$ and the relative humidity from 70 to $99 \%$. The thermal comfort indicator are generally based on prediction of percentage dissatisfied (PPD) and predicted mean value (PMV). PMV is an index that predicts the mean value of the votes of a large group of persons on seven thermal sensation scales while PPD is an index which shows a quantity prediction of the percentage of thermally dissatisfied people determined from PMV. PMV is the most reliable thermal comfort index. It has proven to provide reliable results for thermal environments close to thermal comfort. The PMV values vary from -3 to +3 according to the thermal sensation scale in Table 2.1.4.1 These standards are assumed as "universal" and thus applicable for every building types, every climatic zones and every populations.

Most of the common thermal indices for indoor conditions are based on this heat balance of the human body (McIntyre, 1980). There are four climatic factors influence the thermal comfort of the human body.

1. Air temperature: Increasing air temperature decreases the body's convective heat loss and its dry respiration heat loss influencing thermal comfort.

2. Radiation: The absorption of solar radiation and the exchange of long-wave radiation from room surfaces strongly affect the state of thermal comfort of the human body in indoor conditions. It is expressed in the form of MRT.

3. Humidity: A change in the humidity of the atmosphere affects thermal sensation in that a person feels warmer, sweatier and uncomfortable. Especially in warm conditions, when both convective heat and radiative heat losses are small, sweat evaporation is an important mechanism in maintaining thermal comfort.
4. Wind speed: Increasing air speed increases the convection heat loss and the evaporation of sweat Strong affecting the state of thermal comfort of human body. air movement is thus a clear advantage in warm and humid climates.

\section{A.4 Thermal comfort standards}

The thermal comfort standards in the world are ISO 7730 and ASHRAE 55. The most common thermal comfort standard is based on the PMV index. The thermal sensation scale of PMV in Table2.1.4.1. The comfort zone of PMV is defined as: $-0.5 \leq \mathrm{PMV} \leq+0.5$. This comfort zone is suitable for both summer and winter.

Table 2.1.4.1 Thermal Sensation scale for PMV index

\begin{tabular}{|l|c|c|c|c|c|c|c|}
\hline Sensation & Cold & Cool & $\begin{array}{c}\text { Slightly } \\
\text { Cool }\end{array}$ & Neutral & $\begin{array}{c}\text { Slightly } \\
\text { Warm }\end{array}$ & Warm & Hot \\
\hline PMV & -3 & -2 & -1 & 0 & 1 & 2 & 3 \\
\hline
\end{tabular}

The ASHRAE comfort standard 55 has one comfort zone for the summer and another for the winter. The activity, clothing and air speed for the summer and winter comfort zones are shown in Table 2.1.4.2. It is thus assumed that in summer the clothing insulation is less and the air speed higher than in winter.

Table 2.1.4.2 Parameters for the summer and winter Comfort zones of ASHRAE comfort standard 55

\begin{tabular}{|c|c|c|}
\hline Parameters & Summer & Winter \\
\hline Activity & $1.2 \mathrm{met}$ & $1.2 \mathrm{met}$ \\
\hline Clothing & $0.5 \mathrm{clo}$ & $0.5 \mathrm{clo}$ \\
\hline Air speed & $.25 \mathrm{~m} / \mathrm{s}$ & $.15 \mathrm{~m} / \mathrm{s}$ \\
\hline
\end{tabular}

\section{METHODOLOGY}

A. Investigated base Case study area: National Games Village, Borsajai, Guwahati

Based on the GMDA building bye-laws and development regulations regarding building heights, street widths and setbacks, an existing model urban area of a residential neighbourhood of National Games Village (Fig. 3.1.1) at Borsajai, Guwahati is selected for Microclimate simulations. The campus was developed by GMDA as a group housing scheme in the year 2007. 616 apartments were sold to individual middle-income group families. Present population is approximately 3080 with a density of 132 apartments/hectare. The entire development is based on Type $\mathrm{D}$ residential sector. The base case study area is a simplified cluster of typical geometric patterns, material properties, facade colours and ground elements. , the head margin in this template measures proportionately more than is customary. This measurement and others are deliberate, using specifications that anticipate your paper as one part of the entire proceedings, and not as an independent document. Please do not revise any of the current designations. 


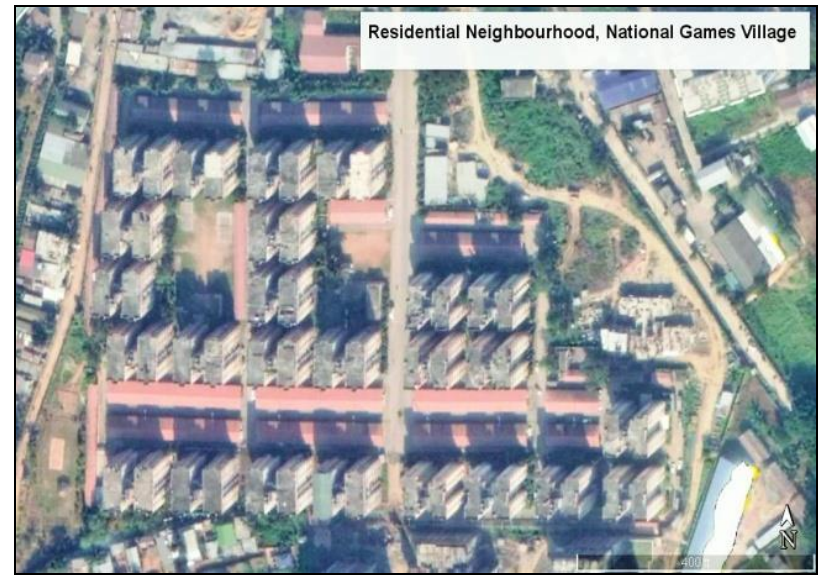

Fig. 3.1.1: satellite map of case study area of National games Village, Borsajai, Guwahati.

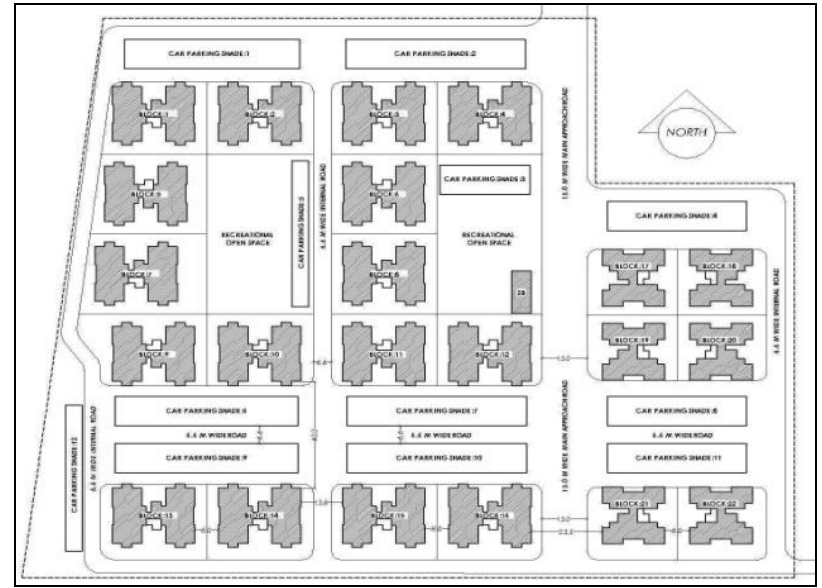

Fig. 3.1.2: Master Plan of Residential neighbourhood of National games Village, Borsajai, Guwahati.

The southern part of the model cluster consists of two rows of plots with six plots on each side of a 6.6 wide road with a 40m wide right of way (Fig. 6.4.3) in E-W direction. The buildings are $21.6 \mathrm{~m}$ high $(\mathrm{G}+6$ floors). The road width is $6.6 \mathrm{~m}$ within the stipulated minimum width of $6.6 \mathrm{~m}$ to $8.0 \mathrm{~m}$. The setbacks are in accordance with the development regulations $($ front $=9.0$ rear setbacks $=6.0 \mathrm{~m}$, side setbacks $=$ $4.0 \mathrm{~m})$. This results in the street height-to-width ratio $(\mathrm{H} / \mathrm{W})$ of $0.54,0.92,1.56$ and 2.70 . The base model has no vegetation.

Table 3.1.1: Input data for the summer and winter base case simulations

\begin{tabular}{|l|l|l|}
\hline Variables/Description & Summer & Winter \\
\hline Building height, $\mathrm{H}(\mathrm{m})$ & 21.6 & 21.6 \\
\hline Distance between buildings, W $(\mathrm{m})$ & $40,23.5,13.8,8$ & $40,23.5,13.8,8$ \\
\hline H/W ratio & $0.54,0.92,1.56,2.7$ & $0.54,0.92,1.56,2.7$ \\
\hline Wind speed (at $1.5 \mathrm{~m}$ height) $(\mathrm{m} / \mathrm{s})$ & 3.0 & 4.0 \\
\hline Max. Indoor temperature $\left({ }^{\circ} \mathrm{C}\right)$ & 33 & 22 \\
\hline U-value, walls $\left(\mathrm{W} / \mathrm{m}^{2}{ }^{\circ} \mathrm{C}\right)$ & 2.77 & 2.77 \\
\hline U-value, roof $\left(\mathrm{W} / \mathrm{m}^{\circ}{ }^{\circ} \mathrm{C}\right)$ & 2.49 & 2.49 \\
\hline Reflectivity, facades & 0.40 & 0.40 \\
\hline \multicolumn{2}{|c|}{0.25} & 0.25 \\
\hline Reflectivity, roofs & 0.25 & 0.25 \\
\hline Reflectivity, street, surface & \multicolumn{2}{|c|}{1.5} \\
\hline $\begin{array}{c}\text { Clothing value (for PMV } \\
\text { calculation) }\end{array}$ & \multicolumn{2}{|c|}{} \\
\hline
\end{tabular}

Guwahati has a warm and humid summer and a dry cold winter, whereas both spring and autumn are quite comfortable. Two base cases are shaped, one for the summer and other for the winter. The summer is represented by 21 June and the winter by 22 December. The input data of the base cases are shown in Table 3.1.1.

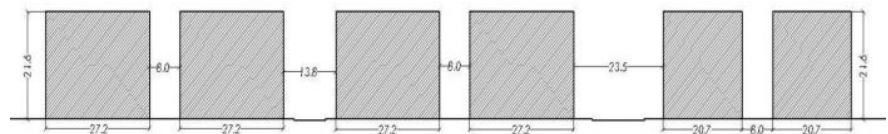

Fig. 3.1.2: section of the model area of the base case with $\mathrm{H} / \mathrm{W}$ ratio of $0.92,1.56,2.70$ in $\mathrm{N}-\mathrm{S}$ direction

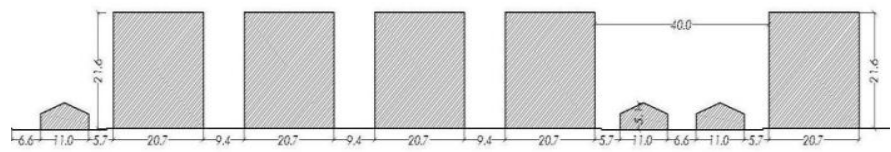

Fig. 3.1.3: section of the model area of the base case with $\mathrm{H} / \mathrm{W}$ ratio of 0.54 in $\mathrm{E}-\mathrm{W}$ direction.

\section{B. Instrumentation}

In this experiment, the equipments that have been used are the Digital Anemometer to measure the wind speed in indoor and outdoor conditions, Max - Min Thermo Hygro Clock TA218B to measure temperature and relative humidity in indoor and outdoor conditions. Both Max - Min Thermo Hygro - Clock TA218B and Digital Anemometer has hygrometer, thermometer, clock, and anemometer device integrated with it. Digital Anemometer has accuracy for wind speed about $\pm 5 \%$, and Max - Min Thermo Hygro - Clock TA218B has an accuracy of air temperature about $\pm 1.2{ }^{\circ} \mathrm{C}$ and relative humidity of $\pm 4 \%$. Both Max - Min Thermo Hygro - Clock TA218B and Digital Anemometer has been used as portable measurement device. Both the equipments are used by placing at 0.6 to 0.9 meter from floor. For outdoor thermal comfort analysis, Envi - Met 4.0 micro climate simulation software is used to find out the PMV level and wind velocity where as Design Builder Energy Plus program has been used to predict the room thermal comfort condition .
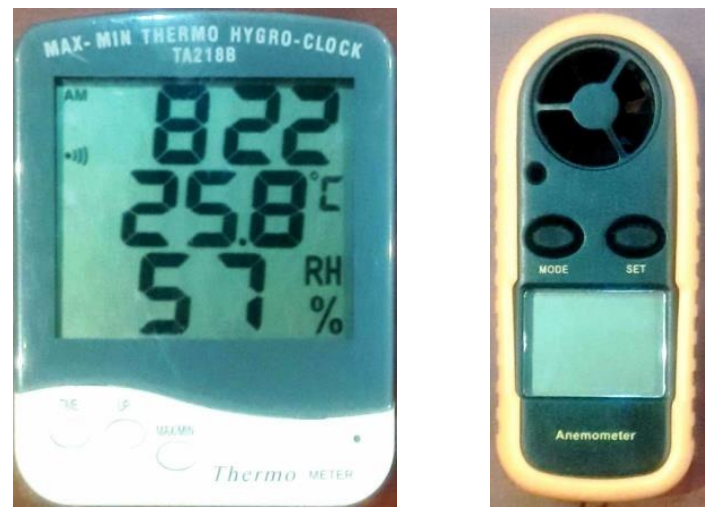

Fig. 3.2.1: Digital Thermo \& Hygrometer, Digital Anemometer

\section{Data collection}

The collection of measurement data consists of three main locations which are the outdoor environment that is located outside the building perimeter, the central open space and the selected indoor rooms. The data taken are air 
temperature, relative humidity, and wind speed. Envi-met simulation data is used for surface temperature and PMV.

The purpose is to find overall temperature modification in the central open space while the other points are to get the air velocity and temperature from different external window opening of the various rooms which offers cross ventilation through the building. The ambient temperature is measured by selected outdoor position which is put outside the building perimeter to get the thermal and wind modification of the surrounding area.

The measured data are air temperature, wind speed infiltration through the windows and door and the relative humidity level. The data that has been measured by the Max Min Thermo Hygro - Clock TA218B and digital anemometer portable unit devices which are indoor air temperature, relative humidity and indoor air speed. All the positions are based on the procedure in ASHRAE standard 55p, 2003.

\section{Measurement position}

The measurement for the indoor position is conducted at $1.1 \mathrm{~m}$ height from floor level at all points. It is the same height for the measurement of the outdoor location and courtyard. It is decided to be $1.1 \mathrm{~m}$ because of consideration of human activities like sitting and standing. According to ASHRAE standard 55p, air temperature and air speed shall be measured at the 0.6 , and $1.1 \mathrm{~m}$.

\section{MICROCLIMATE SIMULATIONS}

To study the thermal impacts of these different parameters, the thermal simulation software ENVI MET 4.0 for outdoor micro climate simulation and Design-Builder Energy Plus is used for indoor simulation. The software ENVI-met, version 4.0 combines the calculation of fluid dynamics parameters such as wind flow and turbulence with the thermodynamic processes taking place on the ground surfaces, walls, roofs and in the vegetation.

\section{A. Outdoor Air temperature}

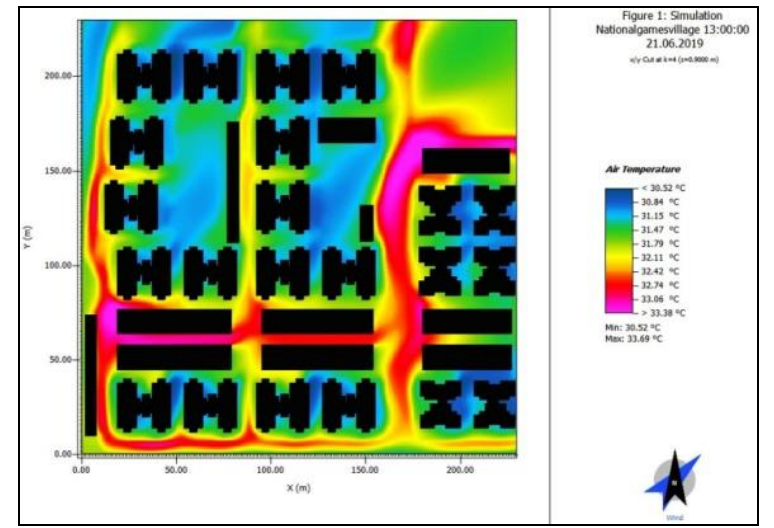

Fig. 4.1.1: Simulation results of air temperature at 1.00pm the summer day (21 June) at a height of $900 \mathrm{~mm}$ from $\mathrm{GL}$.

The simulated outdoor air temperatures are shown in Fig. 4.1.1 (summer) and Fig. 4.1.2 (winter). In general, the air temperature does not vary much between the cases. However the increase of the $\mathrm{H} / \mathrm{W}$ ratio leads to a decrease in maximum air temperature (at around $1.00 \mathrm{pm}$ ), but this decrease is small ( $<1{ }^{\circ} \mathrm{C}$ in summer and $<0.5^{\circ} \mathrm{C}$ in winter). In the summer, the biggest decrease is achieved by using trees and higher reflectivity of the pavements and roads.

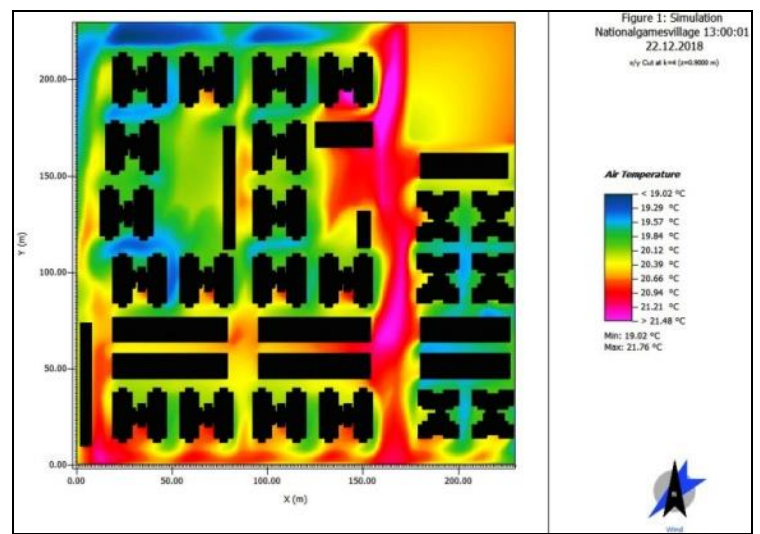

Fig. 4.1.2: Simulation results of air temperature at 1.00pm the winter day (22 December) at a height of $900 \mathrm{~mm}$ from $\mathrm{GL}$.

\section{B. Outdoor Relative Humidity}

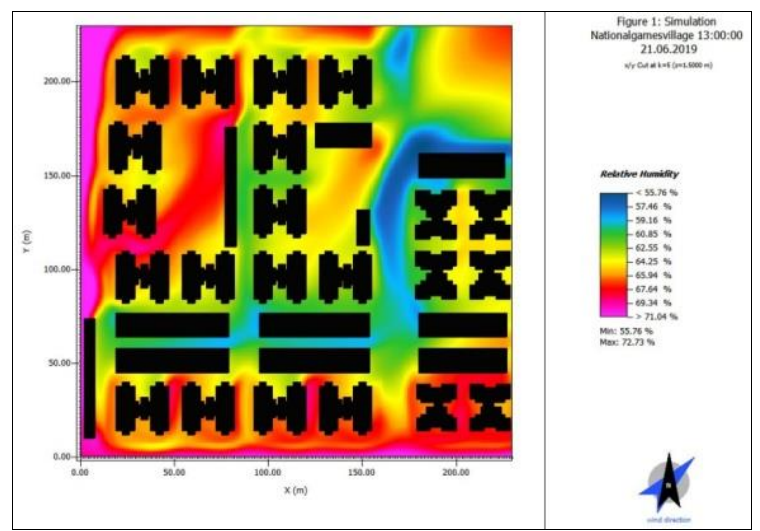

Fig. 4.2.1: Simulation results of Relative Humidity at $1.00 \mathrm{pm}$ the Summer day (21 June) at a height of $900 \mathrm{~mm}$ from $\mathrm{GL}$.

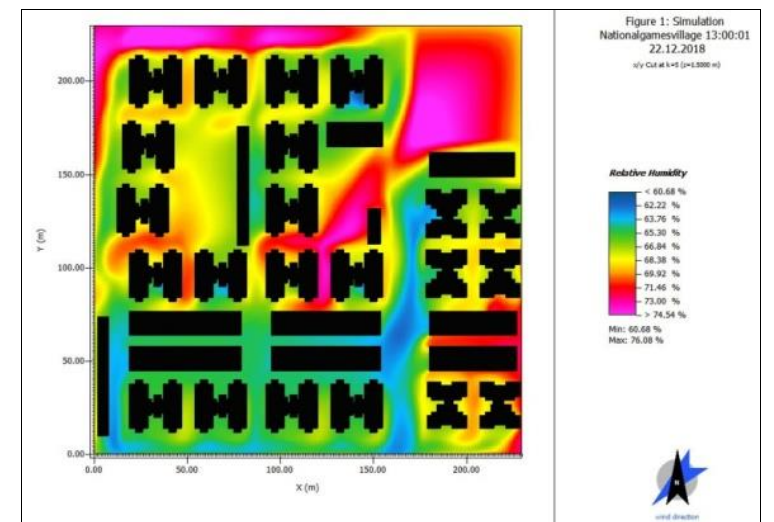

Fig. 4.2.2: Simulation results of air temperature at $1.00 \mathrm{pm}$ the winter day (22 December) at a height of $900 \mathrm{~mm}$ from GL.

The simulated outdoor Relative Humidity is shown in Fig. 4.2.1 (summer) and Fig. 4.2.2 (winter). In general, the Relative Humidity does not vary much between the cases. However the increase of the $\mathrm{H} / \mathrm{W}$ ratio leads to a decrease in maximum Relative Humidity (at around $1.00 \mathrm{pm}$ ), but this 
decrease is small (1-2\% in summer and $3-4 \%$ in winter). In the summer, the biggest decrease is achieved along the wider pavements and roads.

\section{Outdoor Wind Speed}

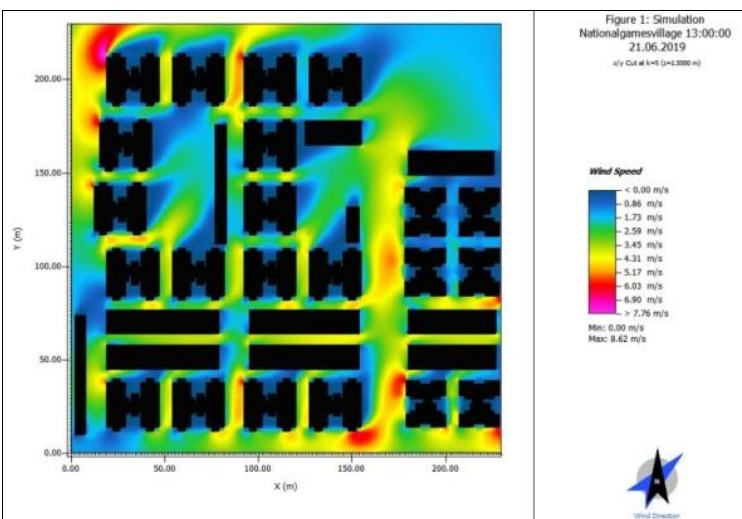

Fig. 4.3.1: Simulation results of Wind speed at 1.00pm the Summer day (21 June) at a height of $900 \mathrm{~mm}$ from $G L$.

The simulated outdoor Wind velocity at various points inside the residential complex is shown in Fig. 4.3.1 (summer) and Fig. 4.3.2 (winter). In the summer, the wind velocity around the blocks varies between $1.73 \mathrm{~m} / \mathrm{s}$ to 4.31 $\mathrm{m} / \mathrm{s}$ where $\mathrm{H} / \mathrm{W}$ ratio $<1$ and wind speed is $5.15 \mathrm{~m} / \mathrm{s}$ when $\mathrm{H} / \mathrm{W}$ ratio $>1$. In the winter, the wind velocity around the blocks varies between $1.30 \mathrm{~m} / \mathrm{s}$ to $3.30 \mathrm{~m} / \mathrm{s}$ where $\mathrm{H} / \mathrm{W}$ ratio $<1$ and wind speed is $4.55 \mathrm{~m} / \mathrm{s}$ when $\mathrm{H} / \mathrm{W}$ ratio $>1$. In both summer and winter, increase in $\mathrm{H} / \mathrm{W}$ ratio leads to the increase in wind speed.

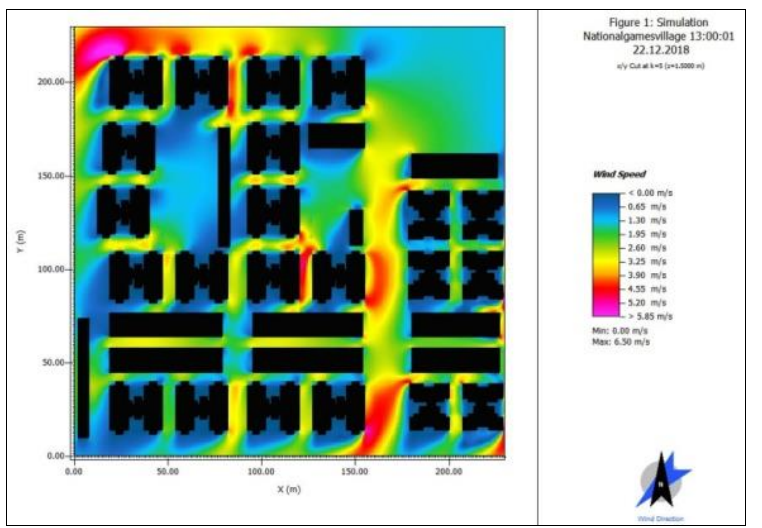

Fig. 4.3.2: Simulation results of wind speed at 1.00pm the winter day (22 December) at a height of $900 \mathrm{~mm}$ from $G L$.

\section{Outdoor thermal comfort}

The outdoor thermal comfort expressed as the PMV index is shown for some of the cases in both summer (Fig. 4.4.1) and winter (Fig. 4.4.2). The PMV in its outdoor version of ENVI-met 4.0 is able summarise the effects of air temperature, MRT, humidity, and wind on the persons energy balance in one value each of it weighted with level of influence. The results are shown for $1 \mathrm{pm}$ in both summer and winter when the solar radiation is significant. In the summer, the height of building shades creates some shading which improves the thermal comfort for pedestrians on the street up to certain extent (Fig. 4.4.1) although the discomfort level of the area is quite high. In winter, PMV remains within +1.11 and -1.11 , the neighbourhood remains comfortable.

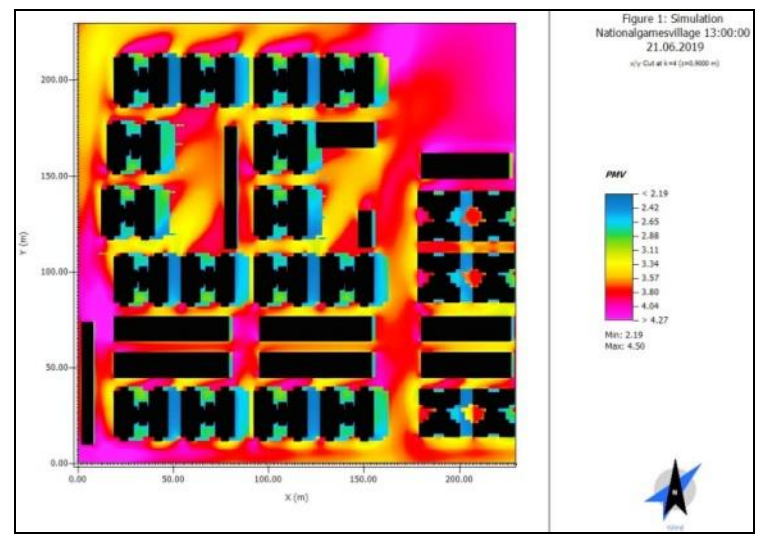

Fig. 4.4.1: Simulation results of PMV at 1.00pm the Summer day (21 June) at a height of $900 \mathrm{~mm}$ from GL.

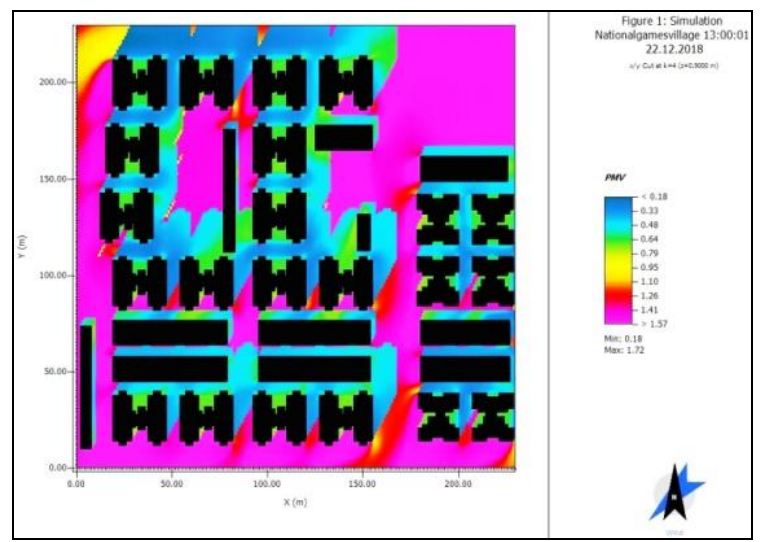

Fig. 4.3.2: Simulation results of PMV at 1.00pm the winter day (22 December) at a height of $900 \mathrm{~mm}$ from $\mathrm{GL}$.

\section{E. Building model for indoor simulation}

The thermal behaviour of a standard apartment is simulated, which is most commonly constructed as residential unit type with the high energy use in the case study area. The following building element parameters are verified in the simulation:

○ External wall

- Window size (WFR)

The comfortable temperature limit for winter and summer are set at $18^{\circ} \mathrm{C}$ and $26^{\circ} \mathrm{C}$ respectively. These values are based on the minimum thermal comfort limits suggested for Guwahati. The objective of using these is to find the minimum energy consumption.

\section{E.1 Ventilation rate and internal loads of typical apartment}

In most apartments in Guwahati, Natural ventilation is achieved by opening windows. There is likely to be natural ventilation (air infiltration) even when the windows are closed. The facade construction is often masonry, which means that most air leakage paths are related to leaky windows. There are air leakage paths e.g. between the window frame and the facade. Ventilation heat losses can add up to an important part of the overall energy losses. Information on ventilation rates are required to calculate the energy use of a building. 
The typical plan of the apartment building model is used for the parametric studies. The computer model is based on a typical middle class apartment of $105 \mathrm{~m}^{2}$, a living and dining hall, a kitchen, two toilets and three bedrooms (Fig. 4.5.1.1). The apartment is on the third floor and has three external walls exposed to the outdoor climate. The internal loads of the different rooms depend on how the apartment is used. The user pattern follows the typical cultural model in Guwahati, such as family size, user behaviour (opening and closing windows for ventilation) and domestic energy use. The resulting internal loads and ventilation rates are listed in Tables 4.5.1.3-4.5.1.5.

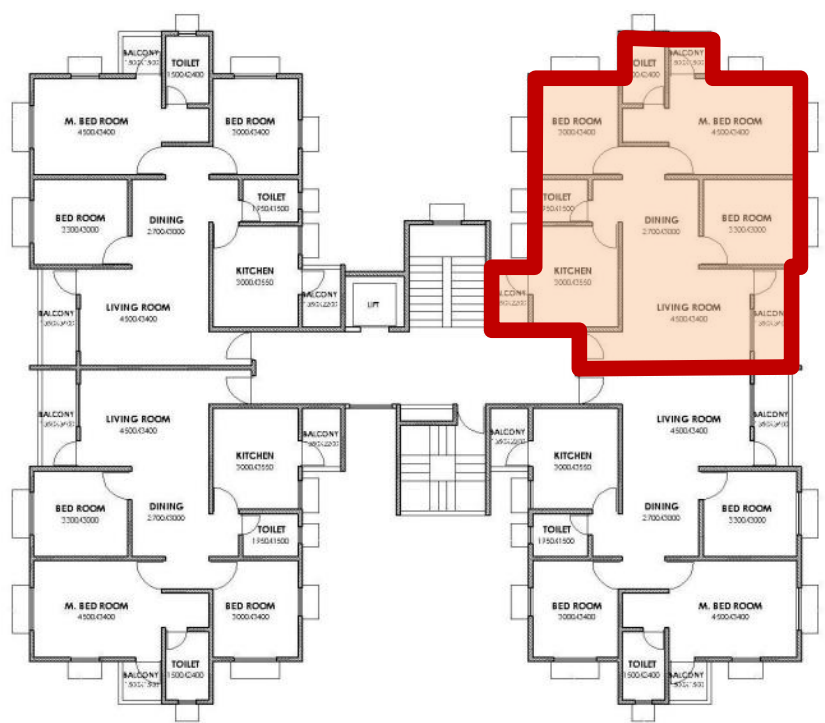

Fig 4.5.1.1: Floor plan of the typical 3BHK apartment in National Games Village

Table 4.5.1.1 Values of surface film thermal resistance for U-value calculation

\begin{tabular}{|c|c|c|c|}
\hline & wall & Roof & \\
\cline { 2 - 4 } & $\begin{array}{c}\text { all climatic } \\
\text { Zones }\end{array}$ & $\begin{array}{c}\text { Composite climate, Hot-Dry climate, Warm- } \\
\text { humid climate, and Temperate climate }\end{array}$ & cold climate \\
\hline $\mathrm{R}_{\mathrm{si}}\left(\mathrm{m}^{2} . \mathrm{K} / \mathrm{W}\right)$ & 0.13 & 0.17 & 0.10 \\
\hline $\mathrm{R}_{\mathrm{se}}\left(\mathrm{m}^{2} . \mathrm{K} / \mathrm{W}\right)$ & 0.04 & 0.04 & 0.04 \\
\hline
\end{tabular}

Source: Bureau of Energy Efficiency (BEE), 2009

External walls are studied according to their thermal performance, principally the thermal insulation. The $u$ value of the exterior wall is calculated (Table 4.5.1.2). Since the Uvalue of the exterior wall is very high at $2.77 \mathrm{~W} / \mathrm{m}^{2}{ }^{\circ} \mathrm{C}$, heat is easily transmitted through wall. The temperature difference between outdoor and indoor condition is very less during summer $\left(2^{\circ}-3^{\circ}\right.$ during summer and $3^{\circ}-4^{\circ}$ during winter).

Table 4.5.1.2: U value Calculations of External wall

\begin{tabular}{|c|c|c|c|c|}
\hline Sl. No & Building Component & $\begin{array}{c}\text { Conductivity-K } \\
\left(\mathrm{W} / \mathrm{m}^{2}{ }^{\circ} \mathrm{C}\right)\end{array}$ & $\begin{array}{c}\text { Thickness - D } \\
\text { in M }\end{array}$ & $\begin{array}{c}\mathrm{R}=\mathrm{D} / \mathrm{K}\left(\mathrm{m}^{2}\right. \\
\left.{ }^{\circ} \mathrm{C} / \mathrm{W}\right)\end{array}$ \\
\hline 1 & Outside plastering & 0.721 & 0.025 & 0.035 \\
\hline 2 & RCC Concrete & 1.58 & 0.150 & 0.095 \\
\hline 3 & Internal plastering & 0.721 & 0.015 & 0.021 \\
\hline 4 & White Wash & 0.05 & 0.002 & 0.04 \\
\hline 5 & $\begin{array}{l}\text { External surface } \\
\text { Resistance }\left(1 / \mathrm{f}_{0}\right)\end{array}$ & & & 0.04 \\
\hline 6 & $\begin{array}{l}\text { Internal surface Resistance } \\
\left(1 / f_{\mathrm{i}}\right)\end{array}$ & & & 0.13 \\
\hline \multicolumn{4}{|c|}{ 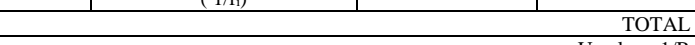 } & 0.361 \\
\hline
\end{tabular}

Table 4.5.1.3 Ventilation rates and internal loads for the period 01 Oct. -31 Dec. (autumn and beginning of winter)

\begin{tabular}{|c|c|c|c|c|c|c|c|c|c|c|}
\hline \multirow[t]{2}{*}{$\begin{array}{l}\text { Hourly } \\
\text { Period }\end{array}$} & \multicolumn{2}{|c|}{ Living Room } & \multicolumn{2}{|c|}{$\begin{array}{l}\text { Master Bed } \\
\text { Room }\end{array}$} & \multicolumn{2}{|c|}{ Bed Room } & \multicolumn{2}{|c|}{ Kitchen } & \multicolumn{2}{|c|}{ Toilet } \\
\hline & $\begin{array}{c}\mathrm{VR} \\
\text { (ach) }\end{array}$ & $\begin{array}{c}\text { IL } \\
(\mathrm{W})\end{array}$ & $\begin{array}{c}\text { VR } \\
\text { (ach) }\end{array}$ & $\begin{array}{l}\mathrm{IL} \\
\text { (W) }\end{array}$ & $\begin{array}{c}\mathrm{VR} \\
\text { (ach) }\end{array}$ & $\begin{array}{c}\text { IL } \\
(\mathrm{W})\end{array}$ & $\begin{array}{c}\text { VR } \\
\text { (ach) }\end{array}$ & $\begin{array}{c}\text { IL } \\
\text { (W) }\end{array}$ & $\begin{array}{c}\mathrm{VR} \\
\text { (ach) }\end{array}$ & $\begin{array}{c}\mathrm{IL} \\
\text { (W) }\end{array}$ \\
\hline $01-06$ & 0.5 & 10 & 0.5 & 50 & 0.5 & 50 & 0.5 & 10 & 0.25 & 10 \\
\hline $07-09$ & 1 & 50 & 1 & 500 & 1 & 500 & 1 & 150 & 0.25 & 50 \\
\hline $10-14$ & 1.3 & 100 & 1.3 & 100 & 1.3 & 100 & 1.3 & 300 & 0.25 & 50 \\
\hline $15-21$ & 1.0 & 100 & 1.3 & 500 & 1.3 & 500 & 1.3 & 300 & 0.25 & 50 \\
\hline $22-24$ & 0.5 & 50 & 0.5 & 150 & 0.5 & 150 & 0.5 & 50 & 0.25 & 10 \\
\hline
\end{tabular}

Table 4.5.1.4 Ventilation rates and internal loads for the period 01 Jan. - 31 May. (Winter and Spring)

\begin{tabular}{|c|c|c|c|c|c|c|c|c|c|c|}
\hline \multirow[t]{2}{*}{$\begin{array}{l}\text { Hourly } \\
\text { Period }\end{array}$} & \multicolumn{2}{|c|}{ Living Room } & \multicolumn{2}{|c|}{$\begin{array}{l}\text { Master Bed } \\
\text { Room }\end{array}$} & \multicolumn{2}{|c|}{ Bed Room } & \multicolumn{2}{|c|}{ Kitchen } & \multicolumn{2}{|c|}{ Toilet } \\
\hline & $\begin{array}{c}\text { VR } \\
\text { (ach) }\end{array}$ & $\begin{array}{c}\mathrm{IL} \\
(\mathrm{W})\end{array}$ & $\begin{array}{c}\text { VR } \\
\text { (ach) }\end{array}$ & $\begin{array}{c}\mathrm{IL} \\
\text { (W) }\end{array}$ & $\begin{array}{c}\text { VR } \\
\text { (ach) }\end{array}$ & $\begin{array}{c}\mathrm{IL} \\
\text { (W) }\end{array}$ & $\begin{array}{c}\text { VR } \\
\text { (ach) }\end{array}$ & $\begin{array}{c}\text { IL } \\
\text { (W) }\end{array}$ & $\begin{array}{c}\text { VR } \\
\text { (ach) }\end{array}$ & $\begin{array}{c}\mathrm{IL} \\
\text { (W) }\end{array}$ \\
\hline $01-06$ & 0.5 & 10 & 0.5 & 50 & 0.5 & 50 & 0.5 & 10 & 0.25 & 10 \\
\hline 07-09 & 0.8 & 50 & 3.06 & 500 & 3.54 & 500 & 2.01 & 150 & 0.25 & 2000 \\
\hline 10-14 & 1.3 & 50 & 3.06 & 100 & 3.54 & 100 & 2.01 & 300 & 0.25 & 2000 \\
\hline 15-21 & 1.3 & 1000 & 3.06 & 1000 & 3.54 & 1000 & 2.01 & 300 & 0.25 & 50 \\
\hline $22-24$ & 0.5 & 300 & 0.5 & 500 & 0.5 & 500 & 0.5 & 100 & 0.25 & 10 \\
\hline
\end{tabular}

Table 4.5.1.6 Ventilation rates and internal loads for the period 01 July. - 31 Sept. (Summer)

\begin{tabular}{|c|c|c|c|c|c|c|c|c|c|c|}
\hline $\begin{array}{c}\text { Hourly } \\
\text { Period }\end{array}$ & \multicolumn{2}{|c|}{ Living Room } & \multicolumn{2}{c|}{$\begin{array}{c}\text { Master Bed } \\
\text { Room }\end{array}$} & \multicolumn{2}{c|}{ Bed Room } & \multicolumn{2}{|c|}{ Kitchen } & \multicolumn{2}{|c|}{ Toilet } \\
\cline { 2 - 12 } & $\begin{array}{c}\text { VR } \\
\text { (ach) }\end{array}$ & $\begin{array}{c}\text { IL } \\
(\text { W) }\end{array}$ & $\begin{array}{c}\text { VR } \\
\text { (ach) }\end{array}$ & $\begin{array}{c}\text { IL } \\
(\text { W) }\end{array}$ & $\begin{array}{c}\text { VR } \\
(\text { ach) }\end{array}$ & $\begin{array}{c}\text { IL } \\
(\text { W) }\end{array}$ & $\begin{array}{c}\text { VR } \\
(\text { ach) }\end{array}$ & $\begin{array}{c}\text { IL } \\
(\text { W) }\end{array}$ & $\begin{array}{c}\text { VR } \\
(\text { ach) }\end{array}$ & $\begin{array}{c}\text { IL } \\
(\text { W) }\end{array}$ \\
\hline $01-06$ & 0.5 & 10 & 0.5 & 2000 & 0.5 & 2000 & 0.5 & 10 & 0.25 & 10 \\
\hline $07-09$ & 1.3 & 50 & 3.56 & 500 & 4.58 & 500 & 2.01 & 150 & 0.25 & 50 \\
\hline $10-14$ & 1.3 & 500 & 3.56 & 500 & 4.58 & 500 & 2.01 & 300 & 0.25 & 50 \\
\hline $15-21$ & 1.3 & 500 & 0.5 & 2000 & 0.5 & 2000 & 2.01 & 300 & 0.25 & 50 \\
\hline $22-24$ & 0.5 & 300 & 0.5 & 2000 & 0.5 & 2000 & 0.5 & 100 & 0.25 & 10 \\
\hline
\end{tabular}

Design Builder Energy plus software is used for indoor simulation of the apartment to find out the indoor temperature, heat gains, energy consumption and ventilation rate (Fig. 4.5.1.2). During summer months average indoor operative temperature remains at $29^{\circ} \mathrm{C}$ and outdoor dry bulb temperature remains at $31^{\circ} \mathrm{C}$. While in winter months indoor operative temperature remains at $23^{\circ}-24^{\circ} \mathrm{C}$ where as outdoor dry bulb temperature remains at $18^{\circ} \mathrm{C}$.

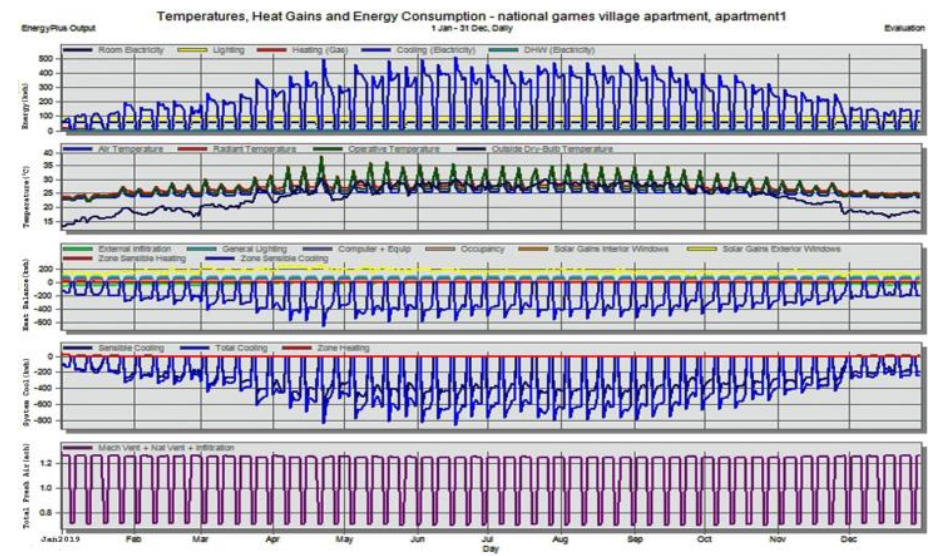

Fig 4.5.1.2: Indoor Temperature, Heat Gains and Energy Consumption of the typical 3BHK apartment in National Games Village throughout the year 2019 based on Design Builder energy plus simulation

\section{E.2 Results and Discussions}

For determining the rate of ventilation based on wind action the wind may be assumed to come from any direction within $45^{\circ}$ of the direction of prevailing wind. Ventilation due to external wind is given by the following formula: 


\section{$\mathrm{Q}=\mathrm{KAV}$}

where

$\mathrm{Q}=$ Rate of air flow in $\mathrm{m}^{3} / \mathrm{h}$

$\mathrm{K}=$ Coefficient of effectiveness, which may be taken as 0.6 for wind perpendicular to openings and 0.3 for wind at an angle less than $45^{\circ}$ to the openings;

$\mathrm{A}=$ Free area of inlet openings in $\mathrm{m}^{2}$; and

$\mathrm{v}=$ Wind speed in $\mathrm{m} / \mathrm{h}$.

For Guwahati apartment the ventilation rate of different rooms are shown in the table 4.2.1 and 4.2.2

The average measured ventilation rate during the winter period is $4.68 \mathrm{ach} \pm 14 \%$. The ventilation rates are not similar in the individual rooms (see Table 4.5.2.1). The ventilation rates are under desirable level except three bed rooms and kitchen. This average temperature difference between the inside and outside is approximately $10^{\circ} \mathrm{C}$ (Table 4.5.1.2 indoor average $+24.2^{\circ} \mathrm{C}$ and outdoor average +14.2 $\left.{ }^{\circ} \mathrm{C}\right)$, the gentle wind speed $(3.0 \mathrm{~m} / \mathrm{s})$, and the fact that the windows are closed most of the time (apart from morning airing). Many building codes recommend a minimum ventilation rate of $0.5 \mathrm{ach}$.

Table 4.5.2.1 Measured ventilation rate in the tested apartment in Guwahati, 14 Dec. - 07 January 2019

\begin{tabular}{|c|l|c|c|c|c|}
\hline $\begin{array}{c}\text { Sr. } \\
\text { No }\end{array}$ & Room & $\begin{array}{l}\text { Room } \\
\text { specific air } \\
\text { flow rate } \\
\text { (ach) }\end{array}$ & WFR (\%) & $\begin{array}{l}\text { Desirable } \\
\text { Air } \\
\text { Change } \\
\text { rate }\end{array}$ & Remark \\
\hline 1 & Living/Dining & $0.80 \pm 0.05$ & $12.00 \%$ & 1.0 & Below desirable Level \\
\hline 2 & Kitchen & $1.41 \pm 0.05$ & $10.00 \%$ & 1.5 & ok \\
\hline 3 & $\begin{array}{l}\text { Master Bed } \\
\text { Room }\end{array}$ & $2.08 \pm 0.05$ & $15.0 \%$ & 0.5 & ok \\
\hline 4 & Bed Room 1 & $2.64 \pm 0.05$ & $25.00 \%$ & 0.5 & ok \\
\hline 5 & Bed Room 2 & $1.45 \pm 0.05$ & $18.00 \%$ & 0.5 & Below desirable Level \\
\hline 6 & Toilet 1 & $0.25 \pm 0.05$ & $12.00 \%$ & 2.0 & Below desirable Level \\
\hline 7 & Toilet 2 & $0.30 \pm 0.05$ & $15.00 \%$ & 2.0 & \\
\hline
\end{tabular}

The average measured ventilation rate during the summer period is $5.93 \mathrm{ach} \pm 14 \%$. The ventilation rates are similar in the individual rooms (see Table 4.3.2). The ventilation rates are fairly high. This is due to the fact that many windows are half opened during the day and night. The driving forces for the ventilation are fairly good. The average temperature difference between inside and outside is $5^{\circ} \mathrm{C}$ (indoors average $+25.4{ }^{\circ} \mathrm{C}$ and outdoors average $+30.4{ }^{\circ} \mathrm{C}$ ), and the wind speed is $4.0 \mathrm{~m} / \mathrm{s}$.

Table 4.2.2 Measured ventilation rate in the tested apartment

\begin{tabular}{|c|l|c|c|c|c|}
\multicolumn{6}{|c|}{ in Guwahati, 14 July - 07 August 2019} \\
\hline $\begin{array}{c}\text { Sr. } \\
\text { No }\end{array}$ & Room & $\begin{array}{l}\text { Room } \\
\text { specific air } \\
\text { flow rate } \\
\text { (ach) }\end{array}$ & WFR (\%) & $\begin{array}{l}\text { Desirable } \\
\text { Air } \\
\text { Change } \\
\text { rate }\end{array}$ & Remark \\
\hline 1 & Living/Dining & $0.85 \pm 0.05$ & $12.00 \%$ & 1.0 & Below desirable Level \\
\hline 2 & Kitchen & $1.45 \pm 0.05$ & $25.00 \%$ & 1.5 & ok \\
\hline 3 & $\begin{array}{l}\text { Master Bed } \\
\text { Room }\end{array}$ & $2.15 \pm 0.05$ & $25.00 \%$ & 0.5 & ok \\
\hline 4 & Bed Room 1 & $2.64 \pm 0.05$ & $25.00 \%$ & 0.5 & ok \\
\hline 5 & Bed Room 2 & $1.65 \pm 0.05$ & $18.00 \%$ & 0.5 & ok \\
\hline 6 & Toilet 1 & $0.25 \pm 0.05$ & $12.00 \%$ & 2.0 & Below desirable Level \\
\hline 7 & Toilet 2 & $0.30 \pm 0.05$ & $15.00 \%$ & 2.0 & Below desirable Level \\
\hline
\end{tabular}

\section{CONCLUSION}

In summer, a large WFR creates a comfortable environment in daytime due to natural ventilation with average operative temperatures of $26.4^{\circ} \mathrm{C}$ and $26.1^{\circ} \mathrm{C}$ for $\mathrm{WFR}=18 \%$ and $\mathrm{WFR}=25 \%$ respectively. Hence present GMDA WFR of around $16.67 \%$ is not adequate enough for a passive cooling apartment in Guwahati.

The indoor climate in winter is considerably comfortable with the existing WFR and building elements, with an increase in temperature of $2.3^{\circ} \mathrm{C}$ in the daytime. However it falls below comfort level at night.

\section{REFERENCES}

[1] ASHRAE Standard 55, 1992, Thermal environmental conditions for human occupancy, ASHRAE Inc., Atlanta.

[2] Bureau of Indian Standards (BIS). 2016. National Building Code of India 2016

[3] Eco-Niwas Samhita 2018 (Energy Conservation Building Code for Residential Buildings) Part I: Building Envelope

[4] ENERGY CONSERVATION BUILDING CODE 2017

[5] GMDA Building Bye Laws 2014

[6] Guwahati Master Plan 2025

[7] ISO/WD7730 (2000) Ergonomics of the Thermal Environment Analytical Determination and Interpretation of Thermal Comfort Using Calculation of the PMV and PPD Indices and Local Thermal Comfort.

[8] Kubota, T., Toe, D. H. C., and Ahmad S., The effects of night ventilation technique on indoor thermal environment for residential buildings in hot-humid climate of Malaysia, Energy and Buildings 41 (2009)

[9] Mazumdar, M., 2002, Energy-efficient buildings in India, TERI, New Delhi.

[10] Milne, M. and Givoni, B., 1979, Architectural design based on climate, In Energy Conservation through Building Design, Watson, D. (Ed.), McGraw Hill Book Company, New York

[11] Sharma, A., Dhote, K. K., \& Tiwari, R. Climatic responsive energy efficient passive technique in building, Eighteen National Convention of Architectural Engineers, Jaipur: Maulana Azad National Institute of Technology (2002) .

[12] Singh, M.K. and Mahapatra, S., 2005, Bio-climatic classification of North East India, International Seminar and Exhibition on Nonconventional and Renewable Energies, Energy Efficiency and Sustainability, "Prithvi 2005", 2026 Feb., Thiruvananthapuram, India.

[13] Wayon, D.P., 1973, The role of the environment in buildings today: Thermal aspects (factors affecting the choice of a suitable room temperature), Building International. 